PRACE GEOGRAFICZNE

zeszyt $158,2019,7-25$

doi: 10.4467/20833113PG.19.013.10917

Instytut Geografii i Gospodarki Przestrzennej UJ

Komisja Geograficzna, Polska Akademia Umiejętności

Wydawnictwo Uniwersytetu Jagiellońskiego

\title{
ZRÓŻNICOWANIE WSPÓŁCZESNYCH ALUWIÓW KORYTA LEPIETNICY
}

\author{
Adam Urbaniak, Anna Michno
}

\section{Variances in the present-day alluvia in the Lepietnica river channel}

\begin{abstract}
The paper discusses variances in present-day alluvia in the Lepietnica river channela left bank tributary of the Czarny Dunajec River in southern Poland. The study focused on the characterization of grain size, petrographic content, and degree of rounding. The analysis considers the morphology of the river channel, sources of material influx to the fluvial system, and degree of human impact. Research has shown that variances in alluvia in the Lepietnica are determined largely by catchment geology and regional elements of relief. Mountain areas such as the Gorce Mountains are characterized by the alluvia of larger grain size, more complex petrography, and less rounding. The lower stretch of the Lepietnica found in the Nowotarska-Orawska Basin is characterized by alluvia of smaller grain size, more rounding, and a different petrographic content.
\end{abstract}

Keywords: alluvia, mountain river channel, Lepietnica

Zarys treści: W pracy przedstawiono zróżnicowanie współczesnych aluwiów w profilu podłużnym koryta Lepietnicy, będącej lewostronnym dopływem Czarnego Dunajca. Scharakteryzowano uziarnienie osadów, ich skład petrograficzny i stopień obtoczenia. W interpretacji wyników uwzględniono morfostrukturę koryta, źródła dostawy materiału do systemu fluwialnego, jak również stopień antropogenicznego przekształcenia koryta. Wykazano, że zróżnicowanie aluwiów Lepietnicy jest warunkowane głównie budową geologiczną zlewni i regionalnymi cechami rzeźby. W obszarze górskim (Gorce) współczesne aluwia charakteryzują się większą frakcją, bardziej zróżnicowanym składem petrograficznym i słabszym obtoczeniem. W dolnym odcinku (w obrębie Kotliny Orawsko-Nowotarskiej) aluwia Lepietnicy odznaczają się drobniejszą frakcją, lepszym obtoczeniem i odmiennym składem petrograficznym.

Stowa kluczowe: aluwia, koryto górskie, Lepietnica 


\section{Wstęp}

Obszary górskie charakteryzują się znacznym zróżnicowaniem środowiska przyrodniczego. Cechuje je wysoka energia rzeźby wyrażona dużymi wysokościami względnymi, wzrostem nachylenia stoków, ich większym rozczłonkowaniem oraz znaczną intensywnością procesów morfogenetycznych. Dużą dynamiką charakteryzują się m.in. procesy fluwialne, co zazwyczaj odzwierciedlone jest w morfostrukturze koryt rzecznych. Zróżnicowanie koryt w profilu podłużnym warunkuje rodzaj źródeł dostawy materiału do systemu fluwialnego, a poprzez to wpływa na cechy osadów mineralnych (Brummer, Montgomery 2003). Cechy współczesnych aluwiów w korytach górskich są zależne również od: budowy geologicznej zlewni (Rutkowski, Zuchiewicz 1987; Sokołowski 1987; Malarz 2002, 2003; Heitmuller, Hudson 2009; Dumitriu i in. 2011), rzeźby obszaru (Unrug 1957; Krzemień 1976, 1984), użytkowania terenu (Niemirowski 1974; Froehlich 1982). Również działalność gospodarcza człowieka wpływa na wykształcenie koryt i osadów aluwialnych (m.in.: Petit i in. 1996; Krzemień 2003; Gregory 2006; Wohl 2006; Korpak i in. 2008; Zawiejska i in. 2015; Gorczyca 2016).

Dotychczasowe badania aluwiów w górskich korytach rzecznych dotyczą: roli struktury koryt i jej ewolucji w różnicowaniu cech osadów (Wyżga 1993; Rengers, Wohl 2007), znaczenia procesu abrazji (Goede 1975; Knighton 1980; Kodama 1994; Malarz 2004), selektywnego transportu i sortowania materiału w profilu podłużnym koryta (Brierley, Hickin 1985; Ferguson i in. 1996), rodzaju źródeł materiału mineralnego dostarczanego do koryt (Kaszowski 1965; Krzysztoń, Krzysztoń 1985; Rice, Church 1998; Owczarek 2003, 2008; Sobczak i in. 2012), roli wezbrań w kształtowaniu cech aluwiów (Krzysztoń 1985; Malarz 2002; Zieliński 2003), różnicowania osadów mineralnych na progach drzewnych i skalnych (Słowik-Opoka i in. 2018) oraz wpływu regulacji koryt i eksploatacji materiału na rozwój form korytowych i cech żwirów rzecznych (Surian 2002; Korpak i in. 2008; Wyżga i in. 2010, 2012; Bucała, Radecki-Pawlik 2012; Krzemień i in. 2015; Witkowski, Wysmołek 2015; Zawiejska i in. 2015). Analizowane jest również powstawanie żwirowych form depozycyjnych (Teisseyre 1977; Reid i in. 1992; Giriat i in. 2008).

Cechy osadów aluwialnych posiadają dużą wartość interpretacyjną w realizacji badań dotyczących rozwoju rzeźby. Uważane są za jeden z najważniejszych wskaźników służących do opisu procesów zachodzących w korycie rzeki. Odzwierciedlają rodzaj i intensywność transportu i mogą być wykorzystane jako zmienna świadcząca o stabilności lub niestabilności dna koryta (Bąk, Michalik 2008; Książek i in. 2008). Zróżnicowanie uziarnienia aluwiów jest dobrze widoczne w korytach górskich, gdzie materiał denny jest transportowany okresowo w zależności od energii potoku (Bąk, Michalik 2008; Bąk i in. 2011). W ciekach o naturalnych korytach zazwyczaj obserwuje się zmniejszanie frakcji aluwiów wzdłuż profilu podłużnego koryta i wzrost 
ich obróbki w kierunku ujścia. Natomiast w ciekach o zdegradowanych antropogenicznie korytach uziarnienie, jak również stopień obróbki materiału żwirowego w profilu podłużnym koryta, jest mniej regularne, a wiele cech żwirów zmienia się skokowo. Wyniki dotychczasowych badań pokazują również, że transport materiału przez niektóre formy regulacji (np. progi korekcyjne) daje podobny efekt w obróbce materiału żwirowego jak transport przez naturalne progi i kotły eworsyjne (Gregory, Cullingford 1974). Pośrednio również zmiana cech aluwiów w dłuższym okresie może świadczyć o antropogenicznych przemianach środowiska przyrodniczego w całej zlewni (Wyżga 1993).

Celem pracy jest przedstawienie zróżnicowania współczesnych aluwiów koryta Lepietnicy, której zlewnia obejmuje obszar gór średnich (Gorce) oraz kotliny (Kotlina Orawsko-Nowotarska). Omówiony został wpływ morfostruktury koryta i współczesnych źródeł dostawy materiału na zróżnicowanie uziarnienia, składu petrograficznego i obróbki osadów aluwialnych. W interpretacji zróżnicowania cech aluwiów uwzględniono również stopień antropogenicznego przekształcenia koryta.

\section{Obszar badań}

Zlewnia Lepietnicy, o powierzchni 50,5 km², położona jest w Zewnętrznych Karpatach Zachodnich (makroregion: Beskidy Zachodnie; mezoregiony: Gorce, Pogórze Orawsko-Jordanowskie) oraz w Centralnych Karpatach Zachodnich (makroregion: Kotlina Podhala; mezoregion: Kotlina Orawsko-Nowotarska) (Kondracki 2009). Około 62\% zlewni znajduje się w obrębie Gorców, 28\% na Pogórzu Orawsko-Jordanowskim i ok. $10 \%$ w obrębie Kotliny Orawsko-Nowotarskiej (ryc. 1).

W ujęciu geologicznym podłożem zlewni Lepietnicy jest jednostka magurska (Gorce, Pogórze Orawsko-Jordanowskie) (Watycha 1963; Stupnicka 1997), tylko niewielki południowy jej fragment znajduje się w tektonicznym zapadlisku orawsko-nowotarskim, wypełnionym osadami czwartorzędowymi (Kotlina Orawsko-Nowotarska) (ryc. 1). Jednostkę magurską na tym obszarze budują górnokredowe i paleogeńskie skały formacji magurskiej tworzące tzw. krynicką strefę facjalną (Żytko 1988). Są to: grubo-, średnio- i cienkoławicowe piaskowce, piaskowce zlepieńcowate, zlepieńce, rozdzielone marglami i łupkami (Cieszkowski 2006). Utworami czwartorzędowymi wypełniającymi kotlinę i dno doliny Lepietnicy są piaszczysto-żwirowe osady teras plejstoceńskich oraz holoceńskie osady rzeczne. Lokalnie występują również osady organiczne, a także koluwia osuwisk oraz drobnoziarniste osady proluwialne i deluwia (Watycha 1977; Burtan i in. 1978; Paul, Ryłko 1986).

Rzeźba obszaru badań jest wyraźnie zróżnicowana. Gorce, jako góry średnie, charakteryzują się kopulastymi kulminacjami o wysokościach przekraczających 1000 m n.p.m. (maksymalnie 1310 m n.p.m. - Turbacz). Wysokości względne w tej 
części zlewni wynoszą od $100 \mathrm{~m}$ do ponad $300 \mathrm{~m}$. Wąskie, długie, twardzielcowe grzbiety mają przebieg przeważnie równoleżnikowy i rozcięte są płytkimi przełęczami, o głębokości $10-30 \mathrm{~m}$. Stoki o nachyleniu od $10^{\circ}$ do ponad $20^{\circ}$ są rozcięte gęstą siecią dolin denudacyjnych $\left(3,95 \mathrm{~km} \cdot \mathrm{km}^{-2}\right)$, głównie wciosów i debrzy. Profil podłużny stoków jest zróżnicowany: wypukło-wklęsły, wypukły, schodowy lub prosty (Urbaniak 2016). Zachodnią część zlewni Lepietnicy, położoną w obrębie Pogórza Orawsko-Jordanowskiego, charakteryzują niewysokie i szerokie grzbiety (maksymalnie 810 m n.p.m.). Wysokości względne tego fragmentu zlewni wynoszą zaledwie $80-120 \mathrm{~m}$. Stoki o nachyleniu 7-10 i wypukłym, wypukło-wklęsłym lub prostym profilu podłużnym są rozcięte również gęstą siecią dolin denudacyjnych $\left(3,18 \mathrm{~km} \cdot \mathrm{km}^{-2}\right)$. Południowa, najmniej urozmaicona część zlewni Lepietnicy, należy już do Kotliny Orawsko-Nowotarskiej. Jest to obszar o deniwelacjach 10-60 m. Niskie i szerokie grzbiety wododzielne osiągają wysokość maksymalnie 600 m n.p.m. Stoki o wypukło-wklęsłym profilu podłużnym charakteryzuje nieznaczne nachylenie $\left(\right.$ do $\left.6^{\circ}\right)$, w niewielkim stopniu rozcięte są one dolinami denudacyjnymi $\left(1,65 \mathrm{~km} \cdot \mathrm{km}^{-2}\right)$ (Urbaniak 2016).

Źródła Lepietnicy znajdują się na stokach Turbacza na wysokości 1230 m n.p.m., natomiast ujście do Czarnego Dunajca jest w miejscowości Ludźmierz na wysokości 595 m n.p.m. Koryto Lepietnicy, o długości 20,07 km, charakteryzuje średni spadek $31,64 \%$. Gęstość sieci rzecznej w zlewni wynosi $2,8 \mathrm{~km} \cdot \mathrm{km}^{-2}$ (Urbaniak 2016). Dopływami Lepietnicy są potoki: Obidowiec, Charczanka i Obroczna. Największym dopływem Lepietnicy jest Obidowiec (prawostronny dopływ o długości 4,8 km), jedynie ten dopływ dostarcza do koryta Lepietnicy materiał grubofrakcyjny. Szerokość dna doliny Lepietnicy jest zróżnicowana od kilkudziesięciu metrów w odcinku górnym do około $500 \mathrm{~m}$ w rejonie Klikuszowej i $1 \mathrm{~km}$ w odcinku ujściowym. Lepietnica cechuje się śnieżno-deszczowym reżimem hydrologicznym i średnim rocznym przepływem o wielkości $0,84 \mathrm{~m}^{3} \cdot \mathrm{s}^{-1}$ (dane z wielolecia 1961-1975; Ziemońska 1973). Roczna suma opadów w regionie jest lokalnie zróżnicowana i wynosi od $760 \mathrm{~mm}$ (Nowy Targ) do $1262 \mathrm{~mm}$ (Turbacz). Zróżnicowanie wykazuje również średnia roczna temperatura: od $2,8^{\circ} \mathrm{C}$ (Turbacz) do $5,3^{\circ} \mathrm{C}$ (Nowy Targ) (dane z wielolecia 1952-1961; Hess 1965). Współcześnie w zlewni Lepietnicy lasy zajmują około 45\% jej powierzchni, łąki, pastwiska i użytki rolne około 49\%, natomiast obszary zabudowane około 5\% (Urbaniak 2016).

\section{Metody badań}

W pracy zastosowano kameralne metody badawcze oraz terenowe. W celu poznania środowiska przyrodniczego zlewni Lepietnicy zostały przeanalizowane dostępne materiały kartograficzne (mapy geologiczne, mapy topograficzne) udostępnione 
ze Zbiorów Kartograficznych Instytutu Geografii i Gospodarki Przestrzennej UJ. W terenie wykonano kartowanie geomorfologiczne koryta Lepietnicy, z wykorzystaniem uproszczonej wersji raptularza do charakterystyki struktury koryt, który został opracowany w IGiGP UJ (Kamykowska i in. 1975). Określono spadek koryta, jego szerokość, zlokalizowano i zmierzono występujące w korycie łachy, progi rumowiskowe i skalne, kotły eworsyjne, podcięcia erozyjne. Na łachach określono również frakcję maksymalną największego otoczaka. Rozpoznano występującą w korycie zabudowę hydrotechniczną oraz zlokalizowano miejsca nielegalnej eksploatacji żwirów. Na podstawie przeprowadzonych badań wydzielono 10 odcinków morfodynamicznych koryta (ryc. 1,2) różniących się m.in. spadkiem, liczbą form erozyjnych i akumulacyjnych, zróżnicowaniem ich cech morfometrycznych, a także stopniem antropogenicznego przekształcenia. Wykonane kartowanie geomorfologiczne koryta Lepietnicy miało na celu rozpoznanie prawidłowości wykształcenia koryta, określenie źródeł dostawy materiału do koryta oraz określenie innych czynników, które mogą mieć wpływ na wykształcenie osadów aluwialnych. Analiza uzyskanych wyników była pomocna w sprecyzowaniu rozmieszczenia stanowisk badawczych. Informacje pozyskane w terenie były również podstawą do późniejszych interpretacji wyników analiz wykształcenia osadów.

Badania zróżnicowania współczesnych aluwiów w korycie Lepietnicy przeprowadzono na 11 stanowiskach. Siedem głównych stanowisk (1-7) było rozmieszczonych na dużych łachach wzdłuż biegu koryta, w odcinkach o różnych cechach morfometrycznych zmieniających się wzdłuż biegu. Natomiast 4 stanowiska, nazwane jako uzupełniające, miały na celu określenie bezpośredniego wpływu: progu skalnego (stanowisko Ia/Ib: Ia - powyżej progu, Ib - poniżej progu), podcięcia erozyjnego brzegów skalno-zwietrzelinowych (stanowisko IIa/IIb; IIa - powyżej podcięcia, IIb - poniżej podcięcia), odcinka z zabudową hydrotechniczną (stanowisko IIIa/IIIb: IIIa - powyżej odcinka koryta z dwoma seriami betonowych progów, którym towarzyszą bystrza o zwiększonej szorstkości i umocnienia betonowe brzegów, IIIb - poniżej tego odcinka koryta) oraz podcięcia erozyjnego wyższej terasy (stanowisko IVa/IVb: IVa - powyżej podcięcia, IVb - poniżej podcięcia) na wykształcenie współczesnych osadów aluwialnych koryta Lepietnicy. Stanowiska uzupełniające zostały zlokalizowane bezpośrednio powyżej i poniżej analizowanego elementu struktury koryta. Na każdym stanowisku badawczym przeanalizowano 100 otoczaków. Scharakteryzowano: uziarnienie osadów, skład petrograficzny oraz stopień ich obtoczenia. Materiał do analiz został pobrany z centralnej części łachy (metodą Wolmana). Uziarnienie osadów określono wg klasyfikacji Wentwortha z modyfikacją Krumbeina i Lana, z uzupełnieniami Urbaniak-Biernackiej (Mycielska-Dowgiałło 1995). Skład petrograficzny materiału aluwialnego scharakteryzowano, rozróżniając: piaskowiec drobnoziarnisty, piaskowiec gruboziarnisty, piaskowiec zlepieńcowaty, zlepieniec, piaskowiec kwarcytyczny, granit, kwarc żyłowy, łupek, mułowiec, 
wapień. Natomiast stopień obtoczenia osadów przeanalizowano w 5-stopniowej skali wg uproszczonej klasyfikacji Olszewskiego (1974), w modyfikacji Mycielskiej-Dowgiałło (1995). Wyróżniono otoczaki: nieobtoczone, słabo obtoczone, średnio obtoczone, dobrze obtoczone i popękane. Wyniki analiz zostały zestawione i zinterpretowane w nawiązaniu do zróżnicowania struktury koryta i cech środowiska przyrodniczego zlewni.

\section{Wyniki badań}

\section{Charakterystyka koryta Lepietnicy}

Cechy koryta Lepietnicy w wydzielonych odcinkach morfodynamicznych są znacznie zróżnicowane (ryc. 2). Szerokość koryta wynosi od 0,5 m w odcinku źródłowym (odcinek 1) do 26 m w odcinku ujściowym (odcinek 9), a spadek różnicuje się w zakresie od 3,17\% (odcinek 10) do 64,06\% (odcinek 1). Wzdłuż koryta zidentyfikowano 342 łachy, 121 podcięć erozyjnych, ponad 500 progów skalnych, rumowiskowych lub skalno-rumowiskowych. Stwierdzono również obecność 75 budowli hydrotechnicznych oraz 25 miejsc, w których prowadzona jest nielegalna eksploatacja aluwiów (fot. 1-6). Najwięcej form erozyjnych, wykształconych jako podcięcia brzegów koryta, progi skalne i rumowiskowe, kotły eworsyjne scharakteryzowano w górnym odcinku koryta (tab. 1). Podcięcia brzegów w górnym odcinku koryta (odcinki 1, 2) obejmują lite podłoże i/lub pokrywy zwietrzelinowe. Osiągają one wysokość do $12 \mathrm{~m}$ i są istotnym źródłem dostawy do koryta materiału świeżego, ostrokrawędzistego. Mniej podcięć występuje w odcinku środkowym koryta (odcinki 3-7), które jest uregulowane i objęte zabudową hydrotechniczną. Podcięcia brzegów w dolnym odcinku koryta (odcinki 8-10) są założone w obrębie wyższych teras i są źródłem dostawy do współczesnego koryta dojrzałych, starszych aluwiów. Progi erozyjne występują głównie w górnym i środkowym odcinku koryta (tab. 1). Jednak największą wysokość osiągają one w odcinku źródłowym - do 3,9 m. Wszystkie progi w korycie Lepietnicy są progami ukośnymi lub poprzecznymi względem jego osi, zbudowane są głównie z piaskowców, a w górnym odcinku koryta również ze zlepieńców i łupków. W korycie scharakteryzowano ponad 300 łach. Występują one wzdłuż całego profilu podłużnego koryta, z wyjątkiem odcinka 7. Największa liczba łach występuje w odcinku 1, lecz są to formy niewielkie o długości zazwyczaj kilkudziesięciu metrów. Są one zbudowane z materiału ostrokrawędzistego o frakcji maksymalnie do $80 \mathrm{~cm}$ (tab. 1). Długie i rozbudowane formy akumulacyjne występują w dolnym odcinku koryta, długość pojedynczych form przekracza tam $200 \mathrm{~m}$. Znacząco mniejsza jest na tym odcinku frakcja maksymalna żwirów. W dolnym odcinku koryta zidentyfikowano też najwięcej miejsc nielegalnej eksploatacji aluwiów. Wśród zlokalizowanych 

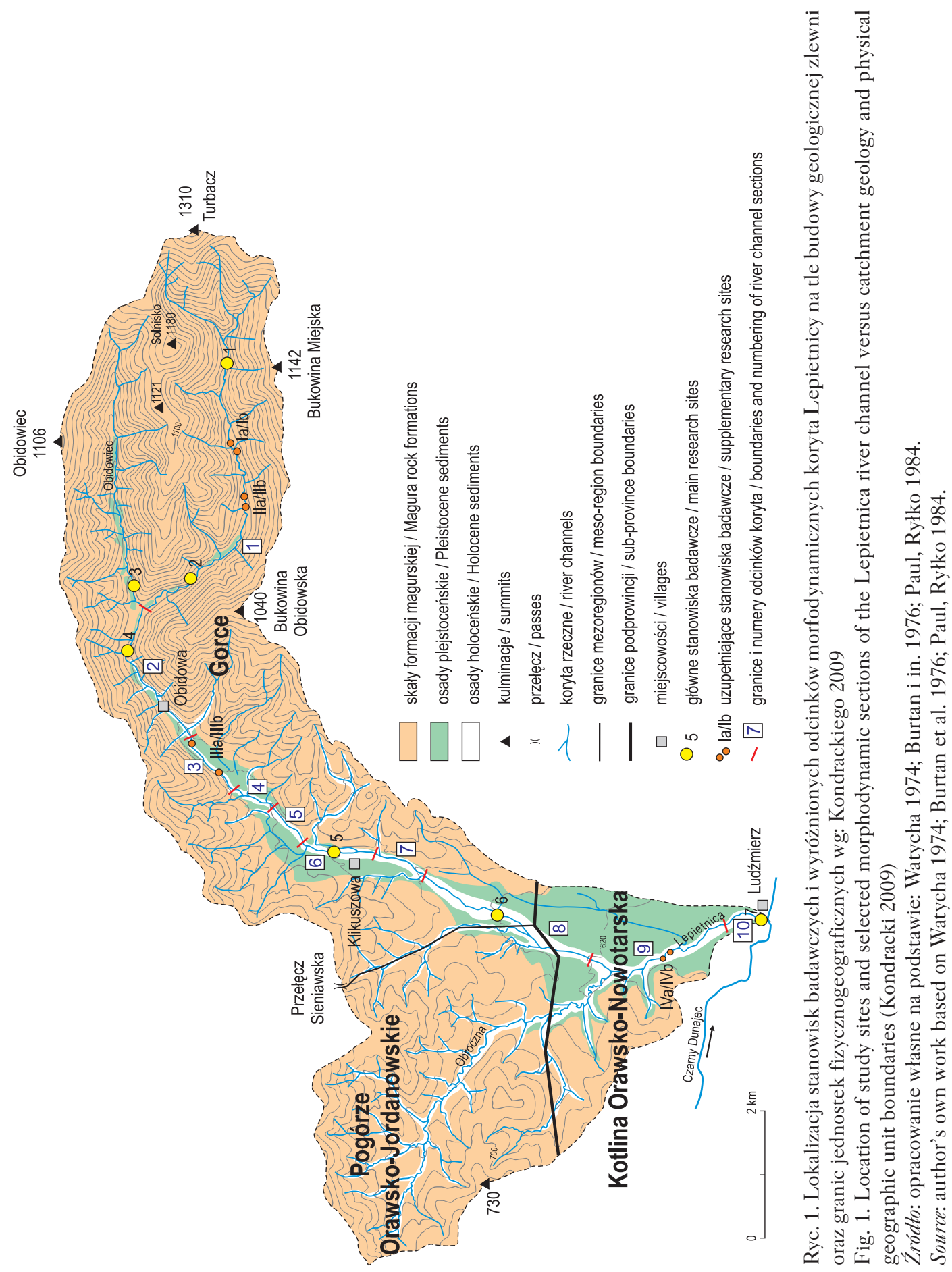


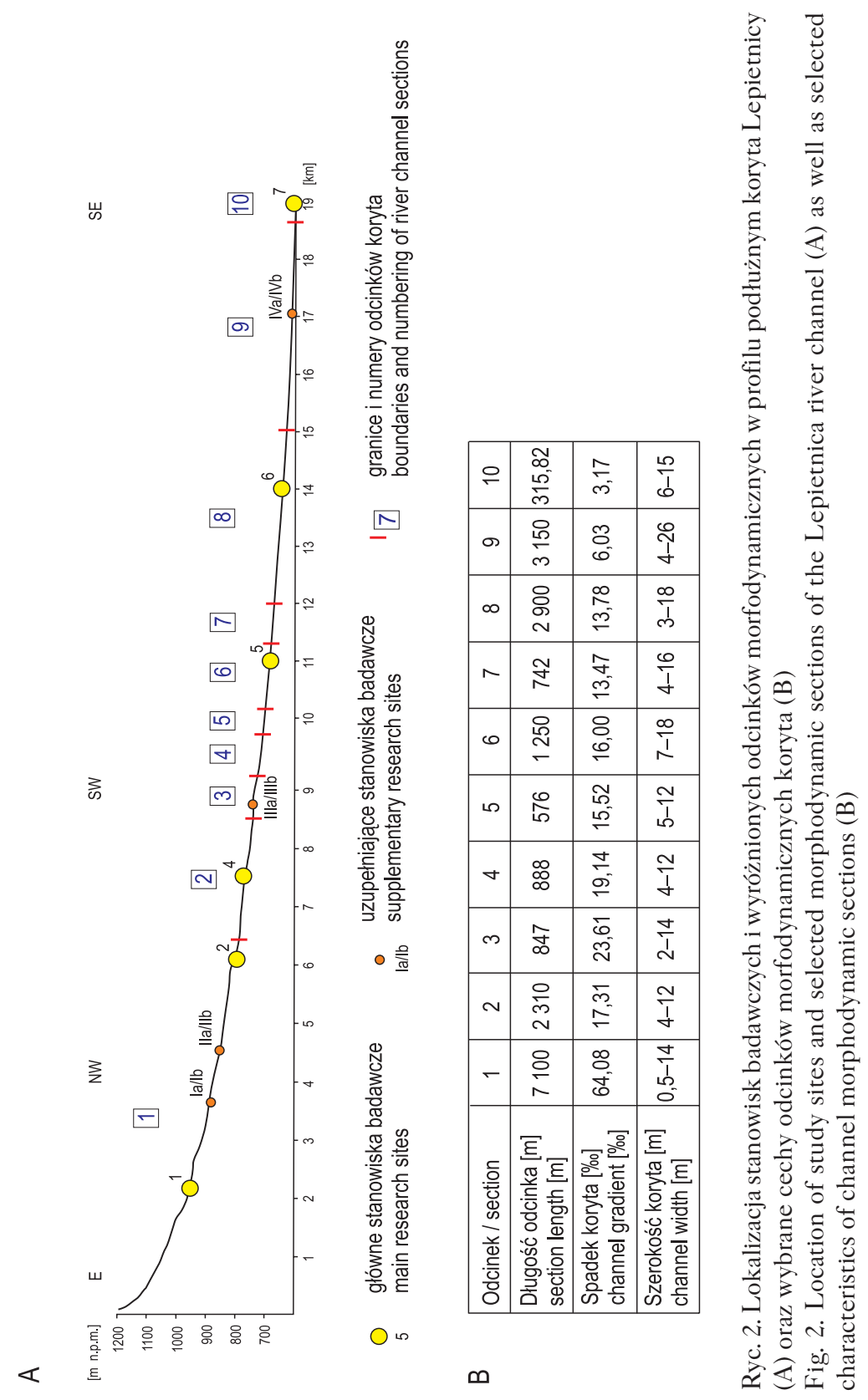




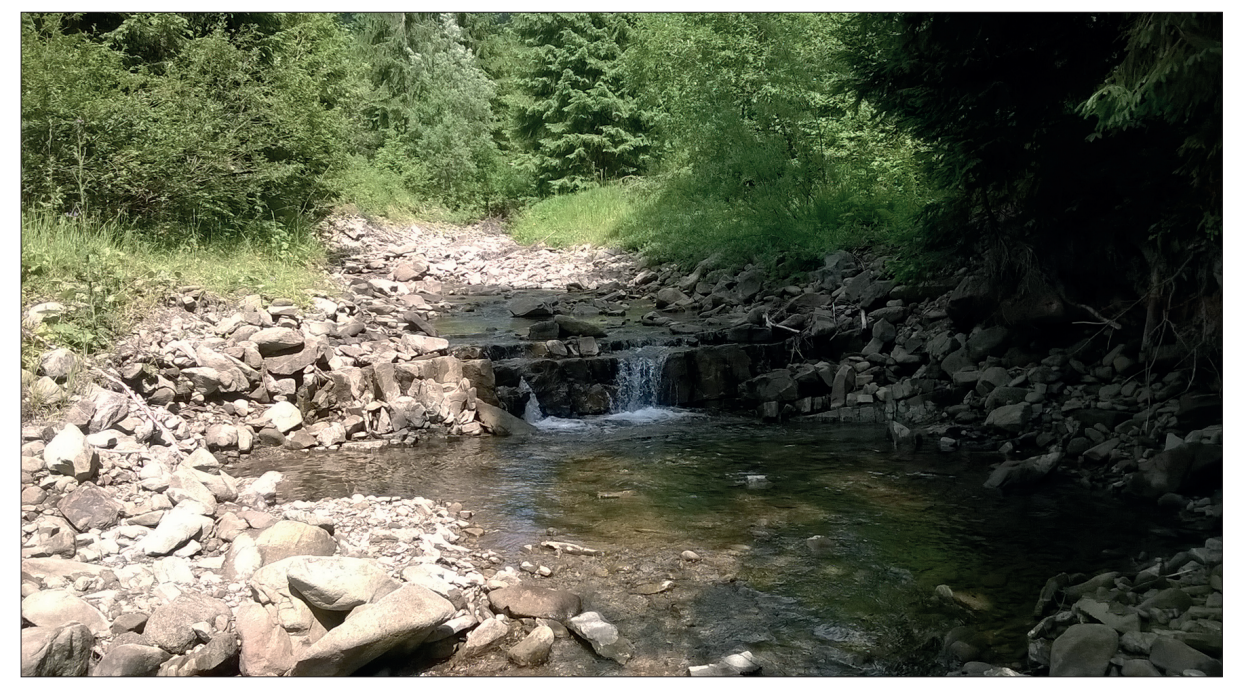

Fot. 1. Próg skalny (odcinek 1)

Photo 1. Rocky step (section 1)

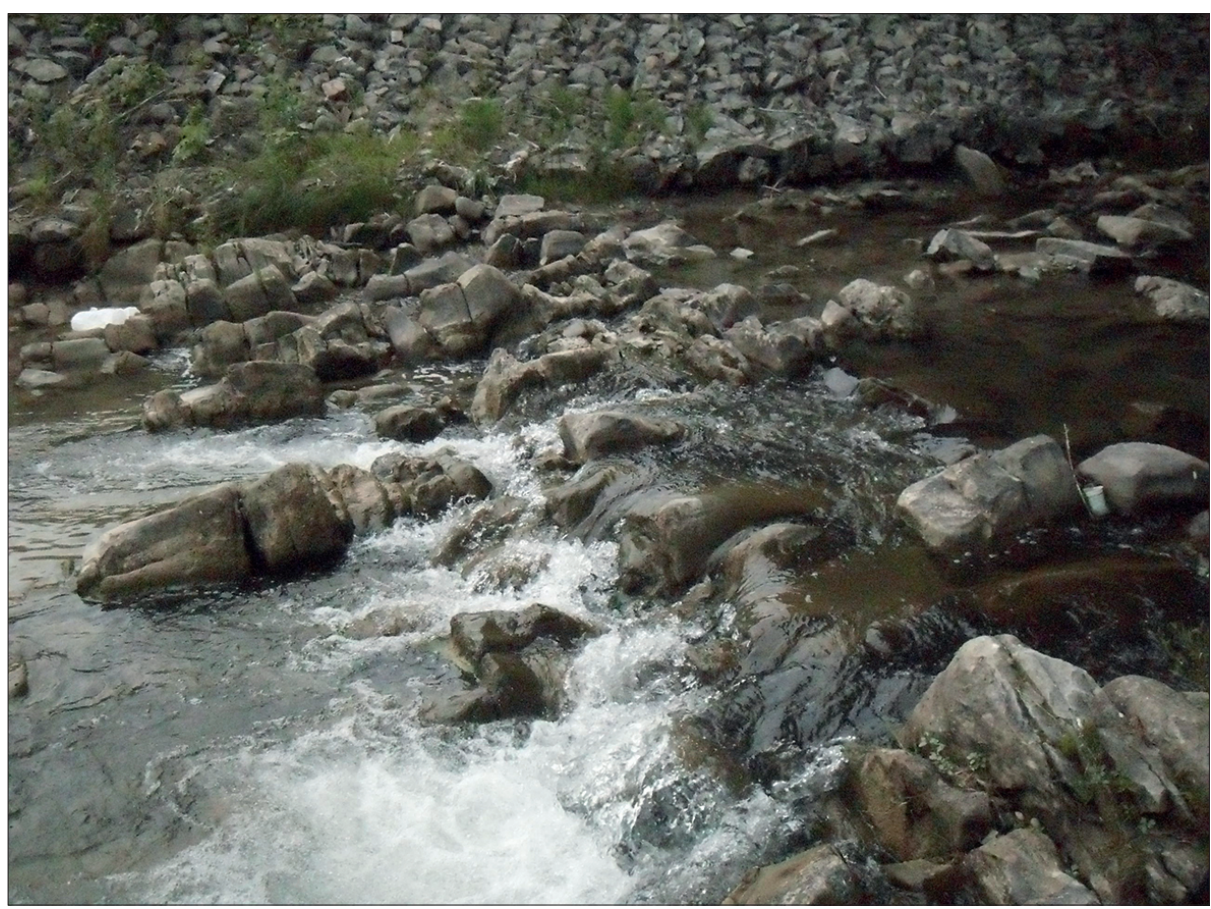

Fot. 2. Skalne progi pod mostem w Klikuszowej (odcinek 6)

Photo 2. Rocky step under the bridge in the town of Klikuszowa (section 6) 


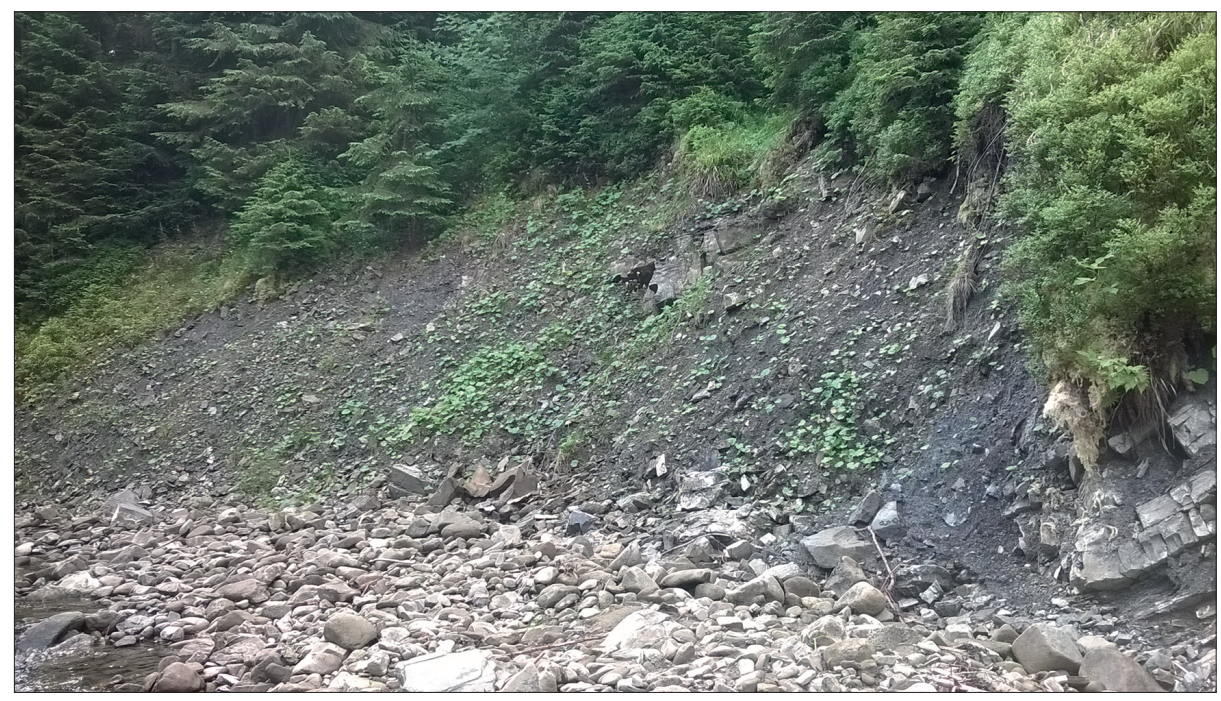

Fot. 3. Podcięcie brzegów skalno-zwietrzelinowych (odcinek 1)

Photo 3. Undercutting the rock and weathering edges (section 1)

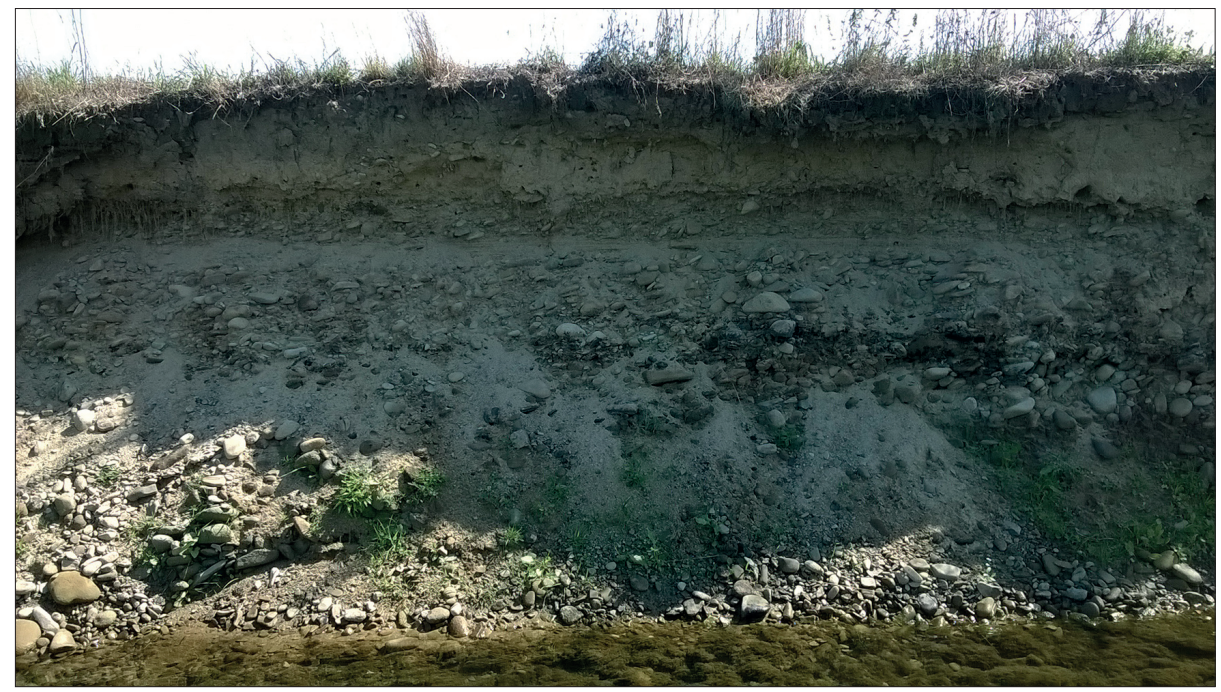

Fot. 4. Podcięcie erozji bocznej w terasie holoceńskiej (odcinek 9)

Photo 4. Lateral erosion undercut on the Holocene terrace (section 9) 


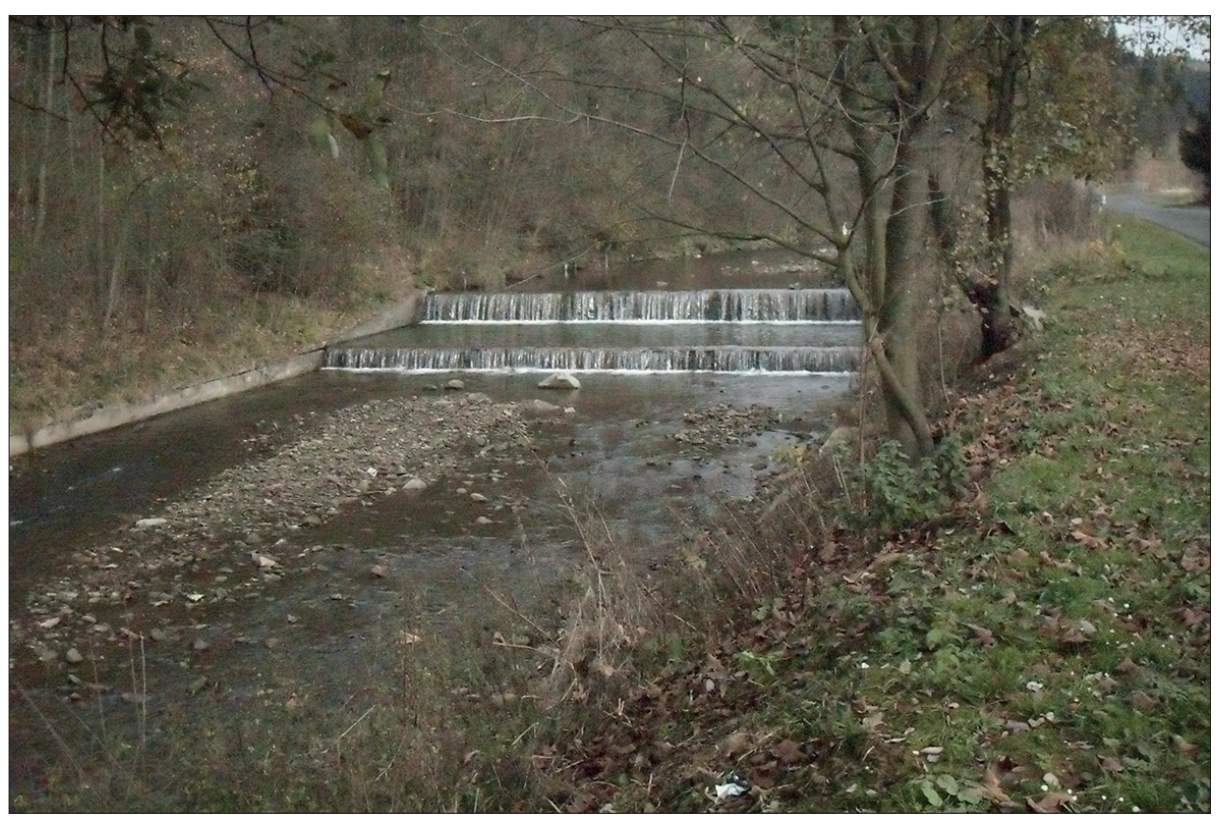

Fot. 5. Betonowe stopnie z towarzyszącymi im betonowymi umocnieniami brzegów (odcinek 3) Photo 5. Concrete drop structures with accompanying concrete bank reinforcements (section 3)

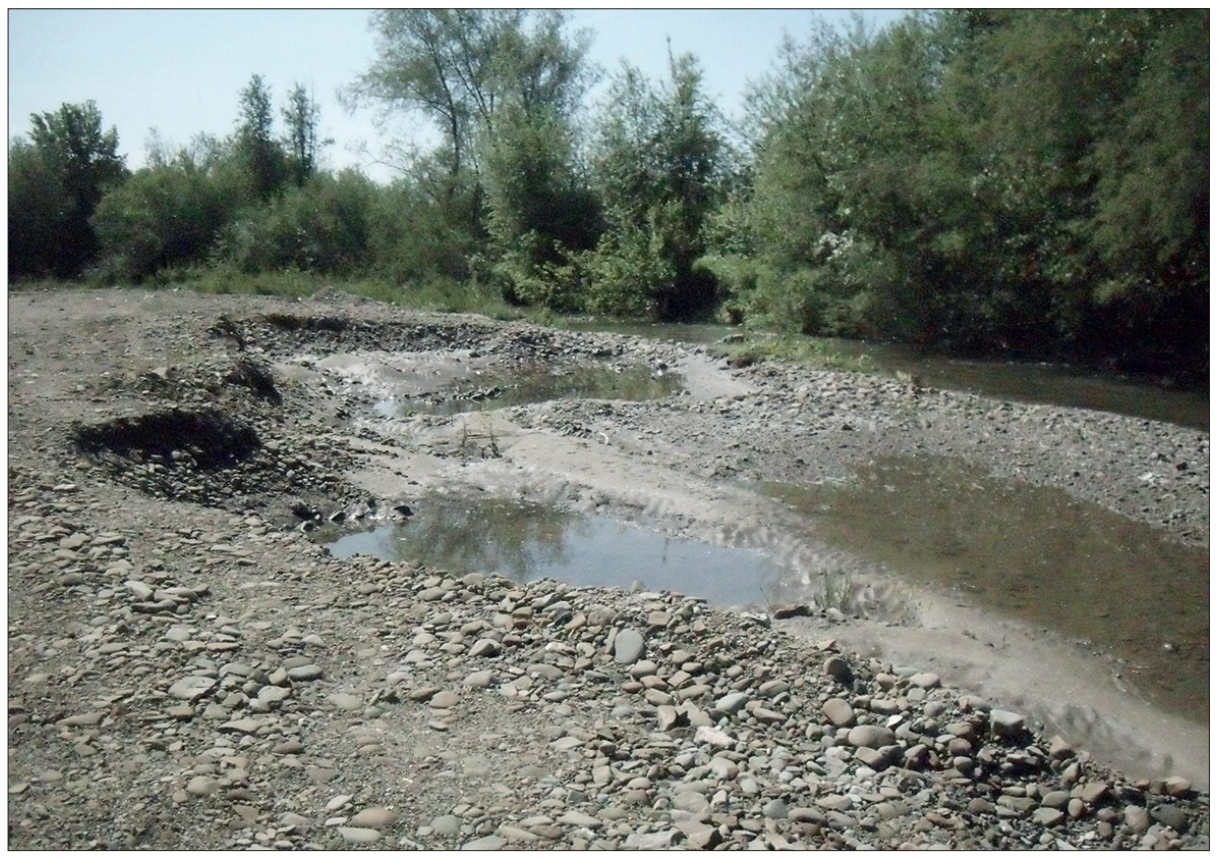

Fot. 6. Ślady po nielegalnej eksploatacji żwirów (odcinek 9)

Photo 6. Sites of illegal gravel extraction (section 9) 


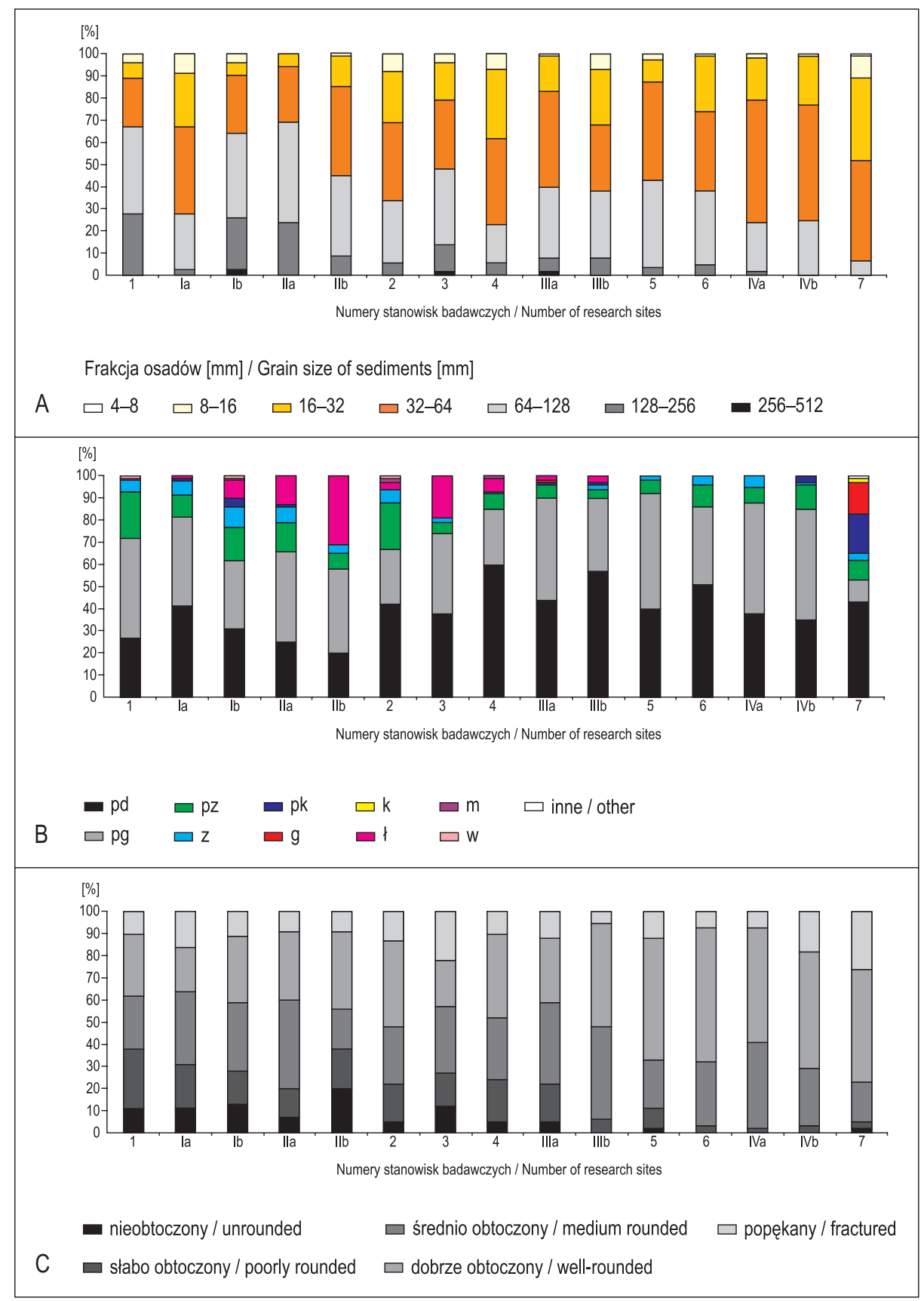

Ryc. 4. Uziarnienie (A), skład petrograficzny (B) i stopień obtoczenia (C) współczesnych osadów aluwialnych Lepietnicy

Fig. 4. Grain size (A), petrographic content (B), and degree of rounding (C) of present-day alluvial sediments in the Lepietnica River

Objaśnienia: pd - piaskowiec drobnoziarnisty, pg - piaskowiec gruboziarnisty, pz - piaskowiec zlepieńcowaty, z - zlepieniec, pk - piaskowiec kwarcytowy, g - granit, k - kwarc żyłowy, $\mathrm{-} \mathrm{-} \mathrm{łupek,} \mathrm{m}$ - mułowiec, w - wapień.

Explanations: pd - fine-grained sandstone, pg - coarse-grained sandstone, $\mathrm{pz}$ - conglomerate sandstone, $\mathrm{z}$ - conglomerate, $\mathrm{pk}$ - quartzite sandstone, $\mathrm{g}$ - granite, $\mathrm{k}$ - quartz, $\mathrm{l}$ - shale, $\mathrm{m}$ - siltstone, $\mathrm{w}$ - limestone. 


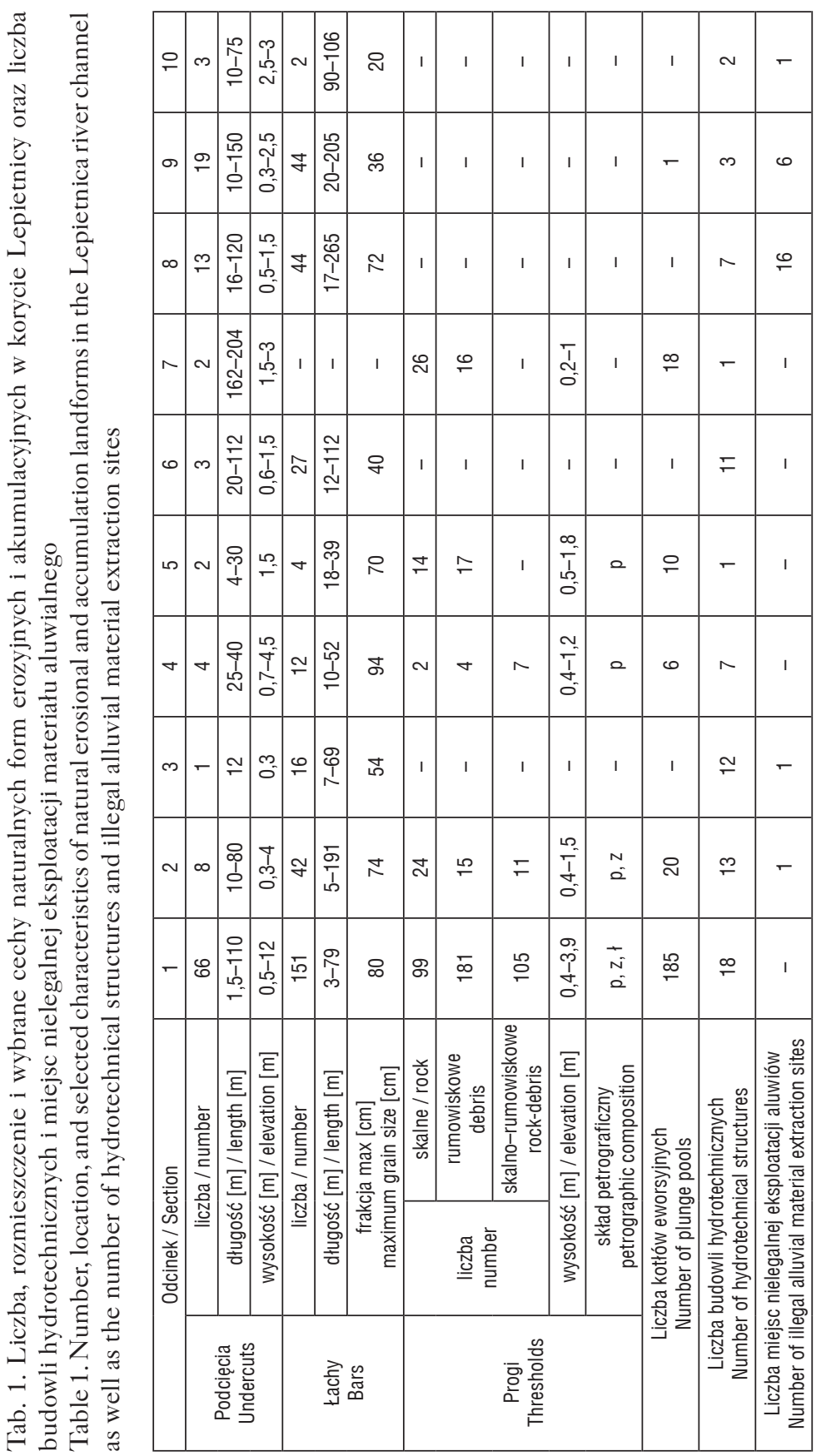


w korycie budowli hydrotechnicznych występują bystrza o zwiększonej szorstkości, jedna zapora przeciwrumowiskowa (odcinek 2), progi betonowe i drewniane oraz gabiony siatkowe wzmacniające brzegi koryta.

Przestrzenne zróżnicowanie morfometrii koryta, liczby form erozyjnych i akumulacyjnych, a zwłaszcza ich cech genetycznych pozwala podzielić cały bieg koryta na 3 odcinki. Górny odcinek (odcinki morfodynamiczne 1,2) ma 9,41 km długości i średni spadek 40,7\%o, charakteryzuje się przewagą procesów erozyjnych (erozja wgłębna i erozja boczna w obrębie wychodni skalnych i pokryw stokowych). Środkowy odcinek koryta (odcinki morfodynamiczne 3-7) o długości 4,29 km i średnim spadku 17,55\%o charakteryzuje się występowaniem licznych, lecz krótkich odcinków o przewadze akumulacji lub erozji. Jest to również odcinek o największym przekształceniu antropogenicznym (zabudowa koryta), co lokalnie decyduje o rozmieszczeniu i intensywności erozji, akumulacji lub tranzytu osadów. Dolny odcinek koryta (odcinki morfodynamiczne 8-10) o długości 6,37 km i średnim spadku 7,66\%o należy już do Kotliny Orawsko-Nowotarskiej i jest typowym odcinkiem akumulacyjnym, w którym lokalnie występują podcięcia erozji bocznej brzegów koryta zbudowanych ze starszych pokryw aluwialnych.

\section{Zróżnicowanie uziarnienia osadów aluwialnych}

Uziarnienie osadów Lepietnicy jest wyraźnie zróżnicowane wzdłuż biegu koryta. Stwierdzono zmniejszający się udział grubofrakcyjnych osadów (bloki duże, bloki małe, otoczaki duże) w dół koryta, rekompensowany osadami o drobniejszej frakcji. Powyższa prawidłowość wyraźnie odróżnia gorczański odcinek koryta od odcinka ujściowego zlokalizowanego w Kotlinie Orawsko-Nowotarskiej.

$\mathrm{Na}$ wszystkich analizowanych stanowiskach zdecydowanie dominują osady o frakcji otoczaków (32-128 mm) - ponad 50\% (ryc. 4A). Największy ich udział występuje na stanowisku $5-83 \%$, a najmniejszy na stanowisku $7-52 \%$. Udział osadów o frakcji bloków (128-512 mm) zmniejsza się od stanowiska 1 (28\%) do stanowiska 7, gdzie osady o tej frakcji w ogóle nie występują. Osady o frakcji żwirów (16-32 mm) wyraźnie zwiększają swój udział od stanowiska $1(11 \%)$ do stanowiska $7(49 \%)$.

Prawidłowości stwierdzone dla profilu podłużnego koryta są modyfikowane przez lokalne źródła dostawy, których znaczenie udokumentowano, prowadząc pomiary na stanowiskach uzupełniających. W przypadku progu skalnego zanotowano wzrost udziału osadów o frakcji bloków i otoczaków dużych poniżej progu (stanowisko Ib), przy równoczesnym spadku udziału osadów o frakcji żwirów. Poniżej podcięcia brzegu skalno-zwietrzelinowego (stanowisko IIb) zaobserwowano sytuację odwrotną kilkunastoprocentowy spadek udziału osadów o frakcji bloków i otoczaków dużych oraz wzrost udziału materiału o frakcji żwirów. Na stanowiskach IVa i IVb, gdzie 
analizowano wpływ erozji bocznej w wyższej terasie, nie zaobserwowano znaczących zmian w uziarnieniu aluwiów poniżej podcięcia. Poniżej uregulowanego odcinka koryta na stanowisku IIIb zanotowano brak osadów o frakcji bloków dużych oraz wzrost udziału osadów o frakcji żwirów w porównaniu z uziarnieniem osadów na stanowisku IIIa (ryc. 4A).

Na oddzielną uwagę zasługują stanowiska 2, 3 i 4 (ryc. 4A). Na stanowisku 3, zlokalizowanym w korycie prawostronnego dopływu Lepietnicy - Obidowca, zanotowano większy udział osadów o frakcji bloków oraz mniejszy osadów o frakcji żwirów w porównaniu ze stanowiskiem 2 w korycie Lepietnicy. Odmienność osadów na stanowisku 3 może wynikać z bliskości dużego podcięcia brzegu koryta Obidowca, skąd pochodzi wyerodowany gruby materiał. Natomiast uziarnienie osadów Lepietnicy na stanowisku 4, poniżej ujścia Obidowca, jest podobne jak na stanowisku 2 (powyżej ujścia Obidowca), co wskazuje, że dopływ ten nie wpływa znacząco na zróżnicowanie uziarnienia osadów w korycie głównym (ryc. 4A).

\section{Zróżnicowanie składu petrograficznego}

Skład petrograficzny osadów koryta Lepietnicy również wykazuje zróżnicowanie w profilu podłużnym. Wzdłuż całego koryta wyraźnie dominują otoczaki z piaskowców drobnoziarnistych i gruboziarnistych, ich łączny udział na poszczególnych stanowiskach przekracza 50\% (ryc. 4B). Najwięcej jest ich na stanowiskach 4, 5 oraz stanowisku 6 w środkowym biegu rzeki, a najmniej w odcinku przyujściowym na stanowisku 7.

Ten sam typ petrograficzny otoczaków dominuje również na stanowiskach uzupełniających, ale tam znaczny jest również udział piaskowców zlepieńcowatych. Największy udział piaskowców zlepieńcowatych zanotowano w górnym odcinku koryta->20\% na stanowiskach 1 i 2. Stwierdzono kilkuprocentowy wzrost ich udziału poniżej progu skalnego na stanowisku Ib. Z kolei poniżej podcięcia brzegu skalno-zwietrzelinowego (stanowisko IIb) badania wykazały mniejszy udział otoczaków z piaskowców zlepieńcowatych, podobnie jak na stanowisku 3 zlokalizowanym poniżej podobnego podcięcia. Jedynie na stanowisku IVb, poniżej podcięcia terasy, udział tych otoczaków wzrósł względem stanowiska IVa (powyżej podcięcia terasy) (ryc. 4B).

$\mathrm{Na}$ badanych stanowiskach stwierdzono także występowanie otoczaków innych petrograficznie niż piaskowcowe. Były one z: łupków, mułowców, piaskowców kwarcytycznych, kwarcu żyłowego, granitu, wapienia. Ich występowanie jest lokalnie znacznie zróżnicowane. Obecność okruchów z łupków stwierdzono tylko w Gorcach (ryc. 4B). Są one charakterystyczne dla stanowisk pomiarowych poniżej aktywnych podcięć erozyjnych (stanowiska IIb, 3), gdzie jest ich zdecydowanie więcej niż powyżej takich podcięć. W górnym odcinku koryta występują również śladowe ilości 
okruchów z mułowców i wapienia, brak takich litotypów w środkowym i dolnym odcinku koryta. Najbardziej zróżnicowanym i odmiennym składem petrograficznym odznacza się stanowisko 7 (ryc. 4B). Oprócz otoczaków z piaskowców drobnoziarnistych, gruboziarnistych, zlepieńcowatych i zlepieńców, stwierdzono kilkunastoprocentowy udział piaskowców kwarcytycznych, granitów i kwarcu żyłowego.

\section{Stopień obtoczenia osadów}

Stopień obtoczenia współczesnych aluwiów Lepietnicy zmienia się wzdłuż biegu koryta. Badania wykazały, że osady wykazują tendencję do coraz lepszego obtoczenia w kierunku ujścia rzeki. Prawidłowość ta jest lokalnie modyfikowana dostawą do koryta materiału z bocznych źródeł i działalnością człowieka. Podobnie jak w przypadku uziarnienia i składu petrograficznego żwirów zauważalna jest dwudzielność analizowanego koryta. W górskim odcinku koryta jest nieco ponad 10\% otoczaków nieobtoczonych i ponad $20 \%$ otoczaków słabo obtoczonych (ryc. 4C). Odsetek otoczaków słabo obtoczonych maleje w dół koryta i już na stanowisku 2 ich udział jest mniejszy o połowę niż na stanowisku 1 . Z kolei liczba otoczaków dobrze obtoczonych stopniowo wzrasta z ponad 20\% (stanowiska 1 do 4 ) do ponad $50 \%$ na stanowisku 5 w Klikuszowej. Udział otoczaków średnio obtoczonych, z wyjątkiem stanowiska 7, przekracza 20\%. Najwięcej jest ich na stanowisku 3, a najmniej na stanowisku 7. Udział otoczaków popękanych jest bardziej zróżnicowany. Na stanowiskach 3 i 7 udział tych otoczaków stanowi ponad 20\%, a na pozostałych stanowiskach kilka - kilkanaście procent.

Powyższe tendencje w obróbce materiału żwirowego lokalnie ulegają zmianom. Poniżej skalnego progu (stanowisko Ib), podobnie jak poniżej podcięć erozyjnych (stanowiska IIb i 3), stwierdzono wzrost udziału otoczaków nieobtoczonych i słabo obtoczonych od kilku do kilkunastu procent. Udział otoczaków średnio obtoczonych poniżej progu skalnego i podcięć był mniejszy, co szczególnie było widoczne pomiędzy stanowiskami IIa i IIb. Ciekawym faktem jest duży udział takich otoczaków na stanowisku 3 w korycie Obidowca, w stosunku do stanowiska 2, mimo bliskości czynnego podcięcia brzegu. Stwierdzono również, że pomiędzy stanowiskami Ia i Ib oraz IIa i IIb udział otoczaków dobrze obtoczonych wykazuje tendencję rosnącą. Tylko na stanowisku 3 otoczaków dobrze obtoczonych było o kilkanaście procent mniej niż na stanowisku 2. Na uregulowanym odcinku koryta (stanowiska IIIa, IIIb) nie stwierdzono otoczaków nieobtoczonych, zdecydowanie zmalał udział otoczaków słabo obtoczonych, ale wzrósł od kilku do kilkunastu procent udział otoczaków średnio i dobrze obtoczonych. W dolnym odcinku koryta Lepietnicy zdecydowanie przeważają otoczaki dobrze obtoczone (ponad 50\%) (ryc. 4C). Znaczny jest tam również udział otoczaków średnio obtoczonych. Stwierdzono również wzrost udziału otoczaków popękanych z $7 \%$ do prawie 30\% na stanowiskach uzupełniających, 
na których badano wpływ dostawy materiału z podciętej terasy na uziarnienie i skład petrograficzny otoczaków. W badanych żwirach dolnego odcinka koryta stwierdzono także niewielki udział otoczaków słabo obtoczonych oraz brak otoczaków nieobtoczonych, z wyjątkiem ich $2 \%$ udziału na stanowisku 7.

\section{Uwarunkowania naturalne i antropogeniczne wpływające na cechy osadów aluwialnych koryta Lepietnicy}

\section{Uwarunkowania naturalne cech osadów aluwialnych}

\section{Uziarnienie osadów}

Osady aluwialne Lepietnicy wykazują tendencję do drobnienia w kierunku ujścia rzeki (ryc. 4A). Tłumaczyć to można procesami rozkruszania i abrazji materiału podczas transportu w korycie. Może to być również efekt transportu selektywnego, w którym eliminowane są z biegiem rzeki otoczaki o największej frakcji. Jest to efekt malejącej z biegiem mocy strumienia i tym samym zdolności do transportu większych otoczaków (Nawara 1960, 1964; Nawara, Stupnicka 1965). Prawidłowość zmniejszania frakcji aluwiów w dół profilu koryta rzecznego wykazali: Malarz (2002, 2003) w korycie Skawy, Soły i Prutu; Niemirowski (1974) w korytach potoków Jaszcze i Jamne; Unrug (1957) w korycie Dunajca; Rengers i Wohl (2007) w Rio Charges; Heitmuller i Hudson (2009) w korycie rzeki Llano; Zawiejska i in. (2015) w korycie Czarnego Dunajca. Tendencja drobnienia osadów wzdłuż profilu podłużnego koryta Lepietnicy ulega zaburzeniu w wyniku dostawy grubszego materiału do koryta z różnych źródeł, między innymi z podcięć brzegów skalno-zwietrzelinowych, progów skalnych oraz z jego dna. W korycie Lepietnicy takie zaburzenia stwierdzono na stanowisku 3 i na stanowiskach Ia i Ib oraz IIa i IIb (ryc. 4A). Można je wiązać z bliskością aktywnego podcięcia brzegu koryta i obecnością progu w korycie, skąd mógł pochodzić grubszy materiał. Przeprowadzona analiza budowy koryta Lepietnicy wskazuje, że w górnym jego odcinku (odcinek 1) głównymi źródłami pochodzenia materiału aluwialnego są podcięte skalne lub skalno-zwietrzelinowe brzegi oraz progi i wychodnie skalne w dnie koryta. Owczarek (2008) oraz Bąk i Michalik (2008) w swoich pracach także podkreślali znaczący wpływ podcięć erozyjnych na różnicowanie wielkości materiału aluwialnego w badanych korytach. Z kolei Malarz (2002, 2003) podkreślał znaczenie dostawy materiału z bocznych dopływów dla zróżnicowania frakcji aluwiów w korycie głównym. Taka prawidłowość nie została stwierdzona w korycie Lepietnicy - tylko na jednym z dopływów Lepietnicy (Obidowiec) zlokalizowane było stanowisko pomiarowe (stanowisko 3). Jedynie ten dopływ dostarcza bowiem materiał grubszy niż zawiesinowy do koryta Lepietnicy. W trakcie badań terenowych zauważono 
natomiast, że miąższość ławic skalnych w podciętych brzegach i w progach korytowych ma znaczenie dla frakcji okruchów skalnych dostarczanych do koryta - frakcja okruchów zależna jest od miąższości ławic. Można tym tłumaczyć wzrost udziału materiału o większej frakcji na stanowiskach 3 i IIb. W dolnym odcinku koryta Lepietnicy (odcinki 8 - 10) głównym źródłem dostawy materiału do transportu fluwialnego są podcięcia piaszczysto-żwirowych starszych teras, co tłumaczy znaczny udział otoczaków o frakcji żwirowej i otoczaków drobnych na stanowiskach 6, 7 oraz IVa i IVb (ryc. 4A). Wyniki badań aluwiów w korycie Lepietnicy potwierdzają zatem naturalne prawidłowości przestrzennej zmienności ich frakcji i pochodzenia, stwierdzane w korytach innych rzek w obszarach górskich.

\section{Skład petrograficzny}

Gorczańska część zlewni Lepietnicy, zbudowana z piaskowców, zlepieńców i łupków jest głównym źródłem pochodzenia współczesnych aluwiów Lepietnicy. Na wszystkich stanowiskach badawczych w korycie zidentyfikowano otoczaki petrograficznie odpowiadające każdemu z miejscowych litotypów (ryc. 4B). W dolnym odcinku koryta nie ma już wychodni skalnych, jego dno i brzegi są wycięte w luźnych osadach czwartorzędowych, dostawa materiału do koryta pochodzi jedynie z podcięć przyległych teras. W związku z tym w składzie petrograficznym współczesnych aluwiów obecne są tylko te otoczaki, które są najodporniejsze i na drodze selektywnego transportu zostały do tego odcinka doniesione przez Lepietnicę, dlatego brak w ich składzie otoczaków z łupków i mułowców. Odmienność składu aluwiów na stanowisku 7 (odcinek 10) należy tłumaczyć obecnością żwirów Czarnego Dunajca w budowie wyższych teras w węzłowym odcinku (zazębianie teras Lepietnicy i Czarnego Dunajca) oraz deponowaniem materiału tatrzańskiego w czasie wezbrań w ujściowym odcinku koryta Lepietnicy.

\section{Stopień obtoczenia osadów}

Według Kaszowskiego (1965) proces obtaczania materiału skalnego podczas transportu postępuje w korycie na długości 4-6 km, po czym pękają one na okruchy i te na podobnym dystansie ponownie ulegają obtoczeniu. Również Nawara (1964) zaznacza, że żwiry o frakcji do 128 mm osiągają dobre obtoczenie na dystansie 7-12 km. Podobne prawidłowości dotyczące zróżnicowania stopnia obtoczenia żwirów w profilu podłużnym koryta stwierdzili także inni autorzy (m.in. Unrug 1957; Niemirowski 1974; Krzemień 1976; Malarz 2002, 2003). Wszyscy podkreślali jednak, że proces obtaczania żwirów ulega zaburzeniu poprzez lokalną dostawę materiału do koryta. Owczarek (2008) stwierdził wzrost liczby otoczaków nieobtoczonych i słabo obtoczonych poniżej podcięć brzegów zbudowanych ze zwietrzeliny. Również 
w Kamienicy Nawojowskiej udokumentowano skokowe zmiany obtoczenia żwirów wzdłuż profilu podłużnego koryta (Krzysztoń, Krzysztoń 1985), co zostało powiązane przez autorów z dostawą nieobtoczonego lub słabo obtoczonego materiału z niewielkich dolin bocznych, w których transport i akumulacja zachodzi głównie podczas gwałtownych wezbrań. W korycie Lepietnicy obecne w górnym odcinku wychodnie oraz progi skalne, a także podcięcia erozyjne, dostarczają świeżych nieobtoczonych okruchów skalnych, co zostało udokumentowane wynikami badań na stanowiskach 3, Ib i IIb (ryc. 4C). Z kolei w dolnym odcinku koryta źródłem dostawy są podcięcia w wyższej terasie. Żwiry budujące terasę są osadem dojrzałym, w większości dobrze obtoczonym. Najprawdopodobniej jest to przyczyną tak dużej dominacji otoczaków dobrze obtoczonych na stanowiskach 5, 6, IVa, IVb i 7. Na tych stanowiskach zauważono też wzrost udziału otoczaków popękanych, co można by tłumaczyć łatwym pękaniem zwietrzałego materiału budującego terasę, włączonego ponownie do transportu fluwialnego.

Dla zróżnicowania współczesnych aluwiów Lepietnicy istotne jest zróżnicowanie cech koryta w profilu podłużnym. W górskim odcinku (Gorce) koryto cechuje się większym spadkiem, niewielką szerokością, jest głęboko wcięte, co przyczynia się do większej energii przepływu (Wyżga i in. 2012) (ryc. 2). W tym odcinku występują w korycie liczne progi skalne i podcięcia brzegów skalno-zwietrzelinowych, a współczesne aluwia charakteryzują się większą frakcją, bardziej zróżnicowanym składem petrograficznym i gorszą obróbką.

W dolnym odcinku (w obrębie Kotliny Orawsko-Nowotarskiej) koryto ma mniejszy spadek - co przekłada się na mniejszą energię transportu, występują też rzadziej podcięcia brzegów i progi skalne oraz inne źródła dostawy świeżego materiału. Współczesne aluwia Lepietnicy w tym odcinku odznaczają się mniejszą frakcją, lepszą obróbką i poszerzonym o materiał tatrzański składem petrograficznym.

\section{Wpływ antropopresji na współczesne aluwia Lepietnicy}

Środkowy odcinek koryta Lepietnicy w obrębie wsi Klikuszowa i Obidowa został uregulowany. Jak zaznaczają w swoich pracach Korpak (2007), Wyżga i in. (2010), Bucała i Radecki-Pawlik (2012), Zawiejska i in. (2015), prace regulacyjne mają kluczowe znaczenie dla funkcjonowania koryta. Przede wszystkim utrudniają lub wręcz uniemożliwiają one dostawę świeżego materiału do koryta, przerywają ciągłość transportu fluwialnego w profilu podłużnym. W korycie Lepietnicy zidentyfikowano budowle poprzeczne i podłużne. Są to sztuczne progi betonowe, częste w środkowym biegu rzeki, progi drewniane, które znajdują się w górnym odcinku koryta. We wsi Obidowa zlokalizowana jest zapora przeciwrumowiskowa oraz liczne sztuczne bystrza. Podłużne budowle regulacyjne reprezentowane są przez gabiony oraz stare betonowe obudowy brzegów. W korycie Lepietnicy poniżej dwóch serii 
betonowych progów, którym towarzyszą bystrza o zwiększonej szorstkości i umocnienia betonowe brzegów (stanowisko IIIb), stwierdzono wzrost udziału osadów o mniejszej frakcji oraz mniejszy udział otoczaków nieobtoczonych i słabo obtoczonych. Wyżga i in. (2012) stwierdza, że odcinki uregulowane spełniają funkcję transportową dla osadów. Wydaje się więc, że najważniejszymi procesami kształtującymi osady w takich odcinkach są ich obróbka mechaniczna i selektywny transport. W przypadku składu petrograficznego aluwiów Lepietnicy wpływ człowieka jest znikomy, co potwierdza m.in. $1 \%$ udziału otoczaków granitowych na stanowisku IIIa, a więc poza występowaniem granitu w podłożu, gdzie zostały one sztucznie wprowadzone do koryta. W Klikuszowej możliwa jest również okresowa dostawa materiału skalnego do koryta Lepietnicy z czynnego kamieniołomu. Antropopresja przejawia się też w procederze nielegalnej eksploatacji żwirów rzecznych z koryta Lepietnicy. Podczas badań zaobserwowano 25 miejsc nielegalnej eksploatacji żwirów. Najwięcej tego typu miejsc zidentyfikowano w odcinku 8 i odcinku 9 (tab. 1). Szczegółowa analiza wpływu tej działalności na cechy współczesnych aluwiów nie była jednak zasadniczym celem pracy. Jak wykazują badania innych autorów (np. Radecki-Pawlik 2002; Rinaldi i in. 2005; Wyżga i in. 2010, 2012; Zawiejska i in. 2015), eksploatacja żwirów z koryta może doprowadzić do wielu niekorzystnych zjawisk, jak erozji wgłębnej, a w konsekwencji też podmywania mostów i innych obiektów hydrotechnicznych.

\section{Wnioski}

Morfostruktura koryta Lepietnicy oraz zróżnicowanie jej współczesnych aluwiów są warunkowane zarówno cechami środowiska przyrodniczego, jak również stopniem antropogenicznego przekształcenia koryta.

Cechy środowiska przyrodniczego zlewni wyraźnie przekładają się na natężenie współczesnych procesów fluwialnych, zróżnicowanie źródeł dostawy materiału do koryta i skład petrograficzny aluwiów. Aluwia w górskich odcinkach koryta, o większym spadku i liczniejszych formach erozyjnych, charakteryzują się większą frakcją i słabszym obtoczeniem, które warunkowane jest lokalną dostawą materiału z podcięć brzegów skalno-zwietrzelinowych oraz z progów skalnych i dna koryta. Natomiast aluwia w odcinkach koryta w obrębie Kotliny Orawsko-Nowotarskiej są drobniejsze. Istotne znaczenie dla ich zróżnicowania mają w tych odcinkach odmienne źródła dostawy, związane z podcięciami starszych, wyższych teras. Odzwierciedla się to również lepszą obróbką materiału i większym udziałem popękanych otoczaków. Cechy aluwiów koryta Lepietnicy w odcinku dolnym, a zwłaszcza ich skład petrograficzny, są znacząco modyfikowane przez dostawę materiału ze starszych poziomów terasowych Czarnego Dunajca, a w odcinku ujściowym także współcześnie z koryta Czarnego Dunajca w okresie wezbrań. 
Uzyskane wyniki wskazują na zachowanie naturalnych prawidłowości w wykształceniu cech osadów aluwialnych w profilu podłużnym koryta Lepietnicy. Mimo iż część koryta została uregulowana, naturalne uwarunkowania wciąż odgrywają decydującą rolę w wykształceniu cech aluwiów.

\section{Literatura}

Bąk Ł., Michalik A., 2008, Zmienność sktadu granulometrycznego rumowiska wleczonego wzdtu: potoku Stomka, Infrastruktura i Ekologia Terenów Wiejskich, 7, 7-18.

Bąk Ł., Michalik A., Tekielak T., 2011, Procesy erozji, transportu i sedymentacji w zlewniach potoków Kasinka i Stomka, Infrastruktura i Ekologia Terenów Wiejskich, 9, 1-86.

Brierley G.J., Hickin E.J., 1985, The downstream gradation of particle sizes in the Squamish River, British Columbia, Earth Surface Processes and Landforms, 10, 597-606.

Brummer C.J., Montgomery D.R., 2003, Downstream coarsening in headwater channels, Water Resources Research, 39 (10), 1294-1307.

Bucała A., Radecki-Pawlik A., 2012, Wpływ regulacji technic»nej na smiany morfologii górskiego potoku:potok Jamne, Gorce, Acta Scientiarum Polonorum Formatio Circumiectus, 10 (1), 3-16.

Burtan J., Paul Z., Watycha L., 1976, Szczegótowa Mapa Geologiczna Polski, 1:50 000, arkusz Mszana Górna, Wydawnictwa Geologiczne, Warszawa.

Burtan J., Paul Z., Watycha L., 1978, Objaśnienia do Szczegótowej Mapy Geologicznej Polski 1:50 000, arkusz Mszana Górna, Wydawnictwa Geologiczne, Warszawa.

Cieszkowski M., 2006, Geologiczne walory naukowe Gorczańskiego Parku Narodowego i jego otocะenia, Ochrona Beskidów Zachodnich, 1, 45-57.

Dumitriu D., Niculita M., Condorachi D., 2011, Downstream variation in the pebble morphometry of the Trotus River, Eastern Carpathians (Romania), Forum geografic. Studii şi cercetări de geografie şi protecția mediului, 10 (1), 78-90.

Ferguson R.I., Hoey T., Wathen S., Werrity A., 1996, Field evidence for rapid downstream fining of river gravels through selective transport, Geology, 24, 179-182.

Froehlich W., 1982, Mechanizm transportu fluwialnego i dostawy swietrzelin do koryta w górskiej zlewni fliswowej, Prace Geograficzne IGiPZ PAN, 143, 1-144.

Giriat D., Kosieradzka K., Roszczęda U., 2008, Mikroformy korytowe typu „,cluster bedforms” występowanie $i$ snaczenie, Landform Analysis, 9, 83-87.

Goede A., 1975, Downstream changes in shape in the pebble morphometry of the Tambo River, eastern Victoria, Journal of Sedimentary Research, 45 (3), 704-718.

Gorczyca E., 2016, Rowwój górskich «̇wirodennych koryt rzecznych w warunkach antropopresji, Instytut Geografii i Gospodarki Przestrzennej UJ, Kraków, 1-240.

Gregory K.J., 2006, The human role in changing river channels, Geomorphology, 79, 172-191. Gregory K.J., Cullingford R.A., 1974, Lateral variations in pebble shape in Northwest Yorkshire, Sedimentary Geology, 12, 237-248. 
Heitmuller F.T., Hudson P.F., 2009, Downstream trends in sediment size and composition of channel-bed, bar, and bank deposits related to hydrologic and lithologic controls in the Llano River watershed, central Texas, USA, Geomorphology, 112, 246-260.

Hess M., 1965, Piętra klimatycznew Polskich Karpatach Zachodnich, Zeszyty Naukowe UJ, Prace Geograficzne, 11, 1-258.

Kamykowska M., Kaszowski L., Krzemień K., Niemierowski M., 1975, Instrukcja do kartowania koryt ræecznych, archiwum Zakładu Geomorfologii IGiGP UJ, Kraków.

Kaszowski L., 1965, Wspótczesne procesy erozji, transportu i sedymentacji w zlewni Potoku Tenczyńskiego, Zeszyty Naukowe UJ, Prace Geograficzne, 12, 43-71.

Knighton A.D., 1980, Longitudinal changes in size and sorting of stream bed material in four English Rivers, Geological Society of America Bulletin, 91 (1), 55-62.

Kodama Y., 1994, Downstream changes in the lithology and grain size of fluvial gravels, the Watarase River, Japan: evidence of the role of abrasion in downstream fining, Journal of Sedimentary Research, A64, 68-75.

Kondracki J., 2009, Geografia regionalna Polski, Wydawnictwo Naukowe PWN, Warszawa.

Korpak J., 2007, Morfologiczna rola budowli regulacyjnych w górskich systemach fluwialnych, praca doktorska, Instytut Geografii i Gospodarki Przestrzennej UJ, Kraków.

Korpak J., Krzemień K., Radecki-Pawlik A., 2008, Wpływ czynników antropogenicznych na zmiany koryt cieków karpackich, Infrastruktura i Ekologia Terenów Wiejskich, 4, 1-89.

Krzemień K., 1976, Wspótcæesna dynamika koryta potoku Konina w Gorcach, Folia Geographica, Series Geographica-Physica, 10, 87-122.

Krzemień K., 1984, Wspótczesne zmiany modelowania koryt potoków w Gorcach, Zeszyty Naukowe UJ, Prace Geograficzne, 59, 83-96.

Krzemień K., 2003, The C:arny Dunajec river, Poland, as an example of human-induced development tendencies in a mountain river channel, Landform Analysis, 4, 57-64.

Krzemień K., Gorczyca E., Sobucki M., Liro M., Łyp M., 2015, Effects of environmental changes and human impact on the functioning of mountain river channels, Carpathians, southern Poland, Annals of Warsaw University of Life Sciences - SGGW, Land Reclamation, 47, 249-260.

Krzysztoń K., Krzysztoń P., 1985, Obtoczenie żwirów piaskowcowych Biatej Dunajcowej i Kamienicy Nawojowskiej (Karpaty fliszowe), Studia Geomorphologica Carpatho-Balcanica, 19, 91-110.

Krzysztoń P., 1985, Cechy ṡwirów tupkowych, powstatych po powodzi w 1983 r. w korycie potoku Binczarka (Beskid Niski), Studia Geomorphologica Carpatho-Balcanica, 19, 77-89.

Książek L., Michalik A., Śladowski T., 2008, Skład usiarnienia rumowiska jako wskaznik lokalnej degradacji koryta ræecznego, Acta Scientiarum Polonorum Formatio Circumiectus, 7 (4), 3-12.

Malarz R., 2002, Powodziowa transformacja grubo klastycznych aluwiow w swirodennych rwekach zachodnich Karpat fliszowych (na przyktadzie Soty $i$ Skawy), Prace Monograficzne, 335, Wydawnictwo Naukowe AP, Kraków.

Malarz R., 2003, Downstream changes of fluvial gravels, the Prut river, Ukraine, Studia Geomorphologica Carpatho-Balcanica, 37, 77-96. 
Malarz R., 2004, The rate of gravel abrasion in the Carpathian rivers, Geografický Časopis, 2, 99-109.

Mycielska-Dowgiałło E., 1995, Wybrane cechy teksturalne osadów $i$ ich wartość interpretacyjna [w:] E. Mycielska-Dowgiałło, J. Rutkowski (red.), Badania osadow czwartorzędowych, Wybrane metody, interpretacja wyników, Wydział Geografii i Studiów Regionalnych UW, Warszawa, 29-105.

Nawara K., 1960, Skład litologiczny żwirów Białki i Czarnego Dunajca w zależności od frakcji, Acta Geologica Polonica, 10 (3), 455-474.

Nawara K., 1964, Transport i sedymentacja wspótczesnych żwirów Dunajca i niektórych jego doptywów, Prace Muzeum Ziemi, 6, 3-11.

Nawara K., Stupnicka E., 1965, Transport i sedymentacja otoczaków piaskowców fliswowych w dolinie Soty, Biuletyn Geologiczny UW, 7, 107-119.

Niemirowski M., 1974, Dynamika wspótcæesnych koryt potoków górskich (na przykładzie potoków Jaszcze i Jamne w Gorcach), Zeszyty Naukowe UJ, Prace Geograficzne, 34, 1-105.

Olszewski A., 1974, Jednostki litofacjalne glin subglacjalnych nad dolnq Wista w świetle analizy ich makrostruktur i makrotekstur, Studia Societatis Scientiarum Torunensis: Geographia et Geologia, 8 (2), 1-145.

Owczarek P., 2003, The variation in clast orientation in mid-mountain river channels under the influence of coarse grained regolith supply, Polish flysh Carpathians, Studia Geomorphologica Carpatho-Balcanica, 37, 97-109.

Owczarek P., 2008, Hillslope deposits in gravel-bed rivers and their effects on the evolution of alluvial channel forms: A case study from the Sudetes and Carpathian Mountains, Geomorphology, 98 (1-2), 111-125.

Paul Z., Ryłko W., 1984, Szčegótowa Mapa Geologicæna Polski, 1:50 000, arkusz Rabka, Wydawnictwa Geologiczne, Warszawa.

Paul Z., Ryłko W., 1986, Objaśnienia do Szczegótowej Mapy Geologicznej Polski, 1:50 000, arkusz Rabka, Wydawnictwa Geologiczne, Warszawa.

Petit F., Poinsart D., Bravard J.P., 1996, Channel incision, gravel mining and bedload transport in the Rhone river upstream of Lyon, France (Canal de Miribel), Catena, 26, 209-226.

Radecki-Pawlik A., 2002, Pobór żwiru i otoczaków z dna potoków górskich, Gospodarka Wodna, 2, 17-19.

Reid I., Frostick L.E., Brayshaw A.C., 1992, Microform roughness elements and the selective entrainment and entrapment of particles in gravel-bed rivers [w:] P. Billi, R.D. Hey, C.R. Thorne, P. Tacconi (red.), Dynamics of gravel-bed rivers, Wiley, Chichester, 253-276.

Rengers F., Wohl E., 2007, Trends of grain sizes on gravel bars in the Rio Chagres, Panama, Geomorphology, 83, 282-293.

Rice S., Church M., 1998, Grain size along two gravel - bed rivers: statistical variation, spatial pattern and sedimentary links, Earth Surface Processes and Landforms, 23, 345-363.

Rinaldi M., Wyżga B., Surian N., 2005, Sediment mining in alluvial channels: physical effects and management perspectives, River Research and Applications, 21, 805-828. 
Rutkowski J.W., Zuchiewicz J., 1987, Petrographic variability of Quaternary fluvial covers in the Dunajec and Poprad valleys, Polish West Carpathians, Studia Geomorphologica Carpatho-Balcanica, 21, 21-41.

Słowik-Opoka E., Wrońska-Wałach D., Michno A., 2018, Analysis of sediment from steps in a small catchment in the Polish Carpathians in relation to the transition sone between the hillslope and fluvial system, Catena, 165, 237-250.

Sobczak K., Biejat K., Dłużewski M., Gierszewski P., Michno A., 2012, Wpływ morfodynamiki koryt ræecznych na dziatalność čtowieka w Atlasie Wysokim (na przyktadzie doliny górnego DadesMaroko), Prace i Studia Geograficzne, 49, 137-150.

Sokołowski T., 1987, Żwiry Dunajca u wylotu z Karpat [w:] L. Starkel, J. Rutkowski (red.), Materiały Sympozjum: Trzecio- i staroczwartorzędowe żwiry Kotliny Sandomierskiej, 22-24.06.1987, AGH, Kraków, 31-33.

Stupnicka E., 1997, Geologia regionalna Polski, Wydawnictwo Uniwersytetu Warszawskiego, Warszawa.

Surian N., 2002, Downstream variation in grain size along an Alpine river: analysis of controls and processes, Geomorphology, 43, 137-149.

Teisseyre A.K., 1977, Pebble cluster as a directional structure in fluvial gravels: modern and ancient examples, Geologia Sudetica, 12 (2), 79-97.

Unrug R., 1957, Wspótczesny transport i sedymentacja żwirów Dunajca (zachodnie Karpaty), Acta Geologica Polonica, 7 (2), 217-257.

Urbaniak A., 2016, Zróśnicowanie osadów ræek górskich na przykładæie Lepietnicy, archiwum Zakładu Geomorfologii IGiGP UJ, Kraków.

Watycha L., 1963, Fliš magurski potudniowej części Gorców, Przegląd Geologiczny, 11 (8), 371-379.

Watycha L., 1974, Szczegótowa Mapa Geologiczna Polski, 1:50 000, arkusz Czarny Dunajec, Wydawnictwa Geologiczne, Warszawa.

Watycha L., 1977, Objaśnienia do Szczegótowej Mapy Geologicznej Polski, 1:50 000, arkusz Czarny Dunajec, Wydawnictwa Geologiczne, Warszawa.

Witkowski K., Wysmołek G., 2015, Wpływ regulacji Skawy na rozwój form korytowych, Landform Analysis, 30, 21-27.

Wohl E., 2006, Human impacts to mountain streams, Geomorphology, 79, 217-248.

Wyżga B., 1993, River response to channel regulation: case study of the Raba River, Carpathians, Poland, Earth Surface Processes and Landforms, 18, 541-556.

Wyżga B., Hajdukiewicz H., Radecki-Pawlik A., Zawiejska J., 2010, Eksploatacja żwirów z koryt rzek górskich - skutki środowiskowe i procedury oceny, Gospodarka Wodna, 6, 243-249.

Wyżga B., Zawiejska J., Radecki-Pawlik A., 2012, Zró̈nicowanie uziarnienia osadów korytowych ræeki górskiej præeksжtatconej præez regulację koryta i eksploatację żwirów, Prace i Studia Geograficzne, 50, 171-179. 
Zawiejska J., Wyżga B., Radecki-Pawlik A., 2015, Variation in surface bed material along a mountain river modified by gravel extraction and channelization, the Ciarny Dunajec, Polish Carpathians, Geomorphology, 231, 353-366.

Zielinski T., 2003, Catastrophic flood effects in alpinelfoothill fluvial system (a case study from the Sudetes Mts, SW Poland), Geomorphology, 54, 293-306.

Ziemońska Z., 1973, Stosunki wodne w polskich Karpatach Zachodnich, Prace Geograficzne IGiPZ PAN, 103, 25-30.

Żytko K. (red.), 1988, Map of tectonic elements of the western outer Carpathians and their foreland, scale 1:500 000, Geological atlas of the western outer Carpathians and their foreland, Państwowy Instytut Geologiczny, Warszawa.

\author{
Adam Urbaniak \\ Uniwersytet Jagiellonski w Krakowie \\ Instytut Geografii i Gospodarki Przestrzennej \\ ul. Gronostajowa 7, 30-387 Kraków \\ adamedwardurbaniak@gmail.com \\ Anna Michno \\ Uniwersytet Jagiellonski w Krakowie \\ Instytut Geografii i Gospodarki Przestrzennej \\ ul. Gronostajowa 7, 30-387 Kraków \\ anna.michno@uj.edu.pl
}

